Portland State University

PDXScholar

$5-22-2020$

\title{
The Pursuit of Democracy: the Racial Subject and Sympathy's Limits in Leaves of Grass
}

Aidan Kennelley

Portland State University

Follow this and additional works at: https://pdxscholar.library.pdx.edu/honorstheses

Part of the English Language and Literature Commons Let us know how access to this document benefits you.

\section{Recommended Citation}

Kennelley, Aidan, "The Pursuit of Democracy: the Racial Subject and Sympathy's Limits in Leaves of Grass" (2020). University Honors Theses. Paper 848.

https://doi.org/10.15760/honors.868

This Thesis is brought to you for free and open access. It has been accepted for inclusion in University Honors Theses by an authorized administrator of PDXScholar. Please contact us if we can make this document more accessible: pdxscholar@pdx.edu. 
The Pursuit of Democracy: The Racial Subject and Sympathy's Limits in Leaves of Grass

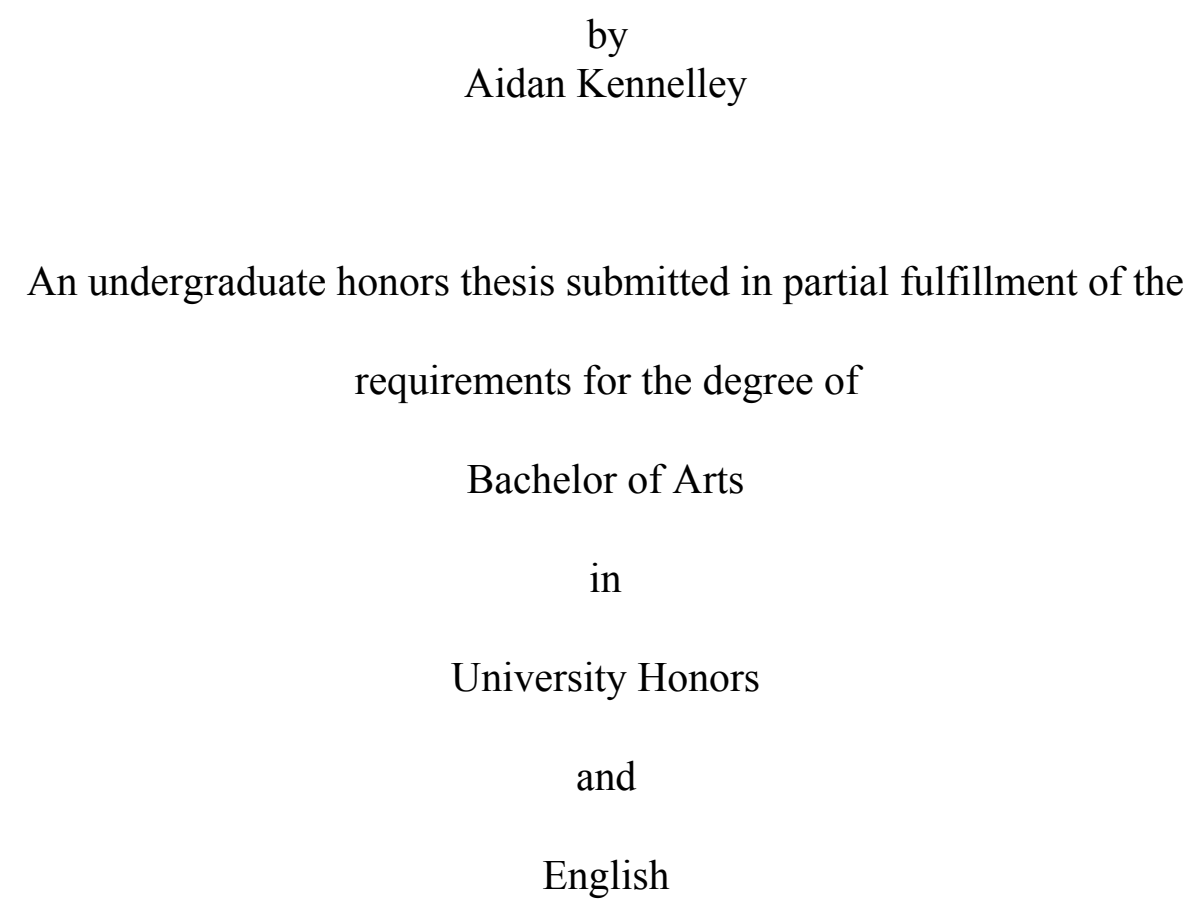

Thesis Advisor

Thomas Fisher, Ph.D.

Portland State University 
Of all nations the United States with veins full of poetical stuff most need poets and will doubtless have the greatest and use them the greatest. Their presidents shall not be their common referee so much as their poets shall. Of all mankind the great poet is the equable man. Not in him but off from him things are grotesque or eccentric or fail of their sanity. Nothing out of its place is good and nothing in its place is bad. He bestows on every object or quality its fit proportions neither more nor less. He is the arbiter of the diverse and he is the key. He is the equalizer of his age and land... Walt Whitman, Preface to Leaves of Grass, 1855 edition

\section{Democracy}

In publishing the first edition of Leaves of Grass, Walt Whitman made his objective clear: he intended to establish himself as America's bard. The 1855 Preface makes this intention explicit, as Whitman spends over 6,000 words making the case for himself as the nation's essential poetic voice. And, of course, immediately after the first edition's publication, Whitman infamously wrote and published three anonymous reviews to bolster his case. In one review, he states, "An American bard at last!...Along his words spread the broad impartialities of the United States. No innovations must be permitted on the stern severities of our liberty and equality" (Whitman, "Walt Whitman and His Poems"). Undoubtedly, Whitman's ambition was to write the great American work of equality, one that concerns itself with breaking down social hierarchies between individuals. His intention was to be the people's poet, a bard who could relay the vast and diverse intricacies of American society through verse. As such, the language of Leaves of Grass is underpinned by the promise of what I call a democratic poetics.

In order to explore Whitman's pursuit of a democratic poetics, it is essential to situate this work within a specific philosophical tradition of democracy. This task can be a difficult one to 
pursue, since democracy, as Wendy Brown comments, “...is among the most contested and promiscuous terms in our modern political vocabulary" (Brown 19). The fundamental challenge in defining democracy comes from identifying what constitutes the demos, the people. We can do this by closely looking at specific instances in the text in which Whitman elaborates his notion of the people. The poet's first exploration of the demos comes in the Preface. He asserts: The American bards shall be marked for generosity and affection and for encouraging competitors...They shall not be careful of riches and privilege...they shall be riches and privilege...they shall perceive who the most affluent man is. The most affluent man is he that confronts all the shows he sees by equivalents out of the stronger wealth of himself. The American bard shall delineate no class of persons not one or two out of the strata of interests nor love most nor truth most nor the soul most nor the body most...and not be for the eastern states more than the western or the northern states more than the southern.

\section{(Whitman 11)}

Here, we see Whitman framing himself as the poet that will capture and represent the pluralities of a society. His insistence that the quintessential American poet "sees by equivalents out of the stronger wealth of himself" foregrounds a desire for a certain metaphysical equality that he

pursues throughout the poem. Further, he moves outside of the metaphysical to establish specific, concrete notions of equality when he proclaims that he "...shall delineate no class of persons." This assertion underscores an ambition to break down social barriers of separation and division and to pursue a promise of pure equality. 
This theme of breaking down class differences continues to figure prominently as we move further into the text. For example, we see another instance of it in the first edition's Song of Myself:

This is the breath of laws and songs and behavior,

This is the tasteless water of souls...this is the true sustenance,

It is for the illiterate...it is for the judges of the supreme court...

it is for the federal capitol and the state capitols,

It is for the admirable communes of literary men and composers and singers and lecturers and engineers and savans,

It is for the endless races of working people and farmers and seamen. (Whitman 34) Whitman's insistence that this work is for people across all professions, social circles, and cultural communities is further elaborated here. And what is striking is his explicit references to working people. Indeed, this is representative of Whitman's support for the free labor movement during this time. Free labor, a concept employed by the Republican Party in pre-antebellum America (approximately the 1850s), specifically dealt with the notion of dignity of labor. It was ideologically rooted in a Protestant ethic that emphasized economic growth and social mobility. ${ }^{1}$ Whitman's specific references to working class people and the poor, his deliberate insistence that the poem is for them and the elites, and his glorification of the dignity of work underscore an attempt at solidarity. They also stem from an ethos of equality, one that insists that each individual has a voice in the conversation of a collective whole.

\footnotetext{
${ }^{1}$ Eric Foner, Free Soil, Free Labor, Free Men
} 
These are just a few of several excerpts that demonstrate the poet attempting to locate and define the demos. And when we look at them collectively, a definition that isn't limited to any specific culture or class of people emerges. A Whitmanian demos strives to name and involve every single part of the whole. This is evident in the poet's lengthy enumerations of different types of people throughout the text, as we see in the aforementioned excerpt from Song of Myself. Certainly, one of his goals is to acknowledge every individual component that, when combined, creates his demos. However, it's important to note his objective is also to alter and reshape the power structures between different sects of the people. Let's return to the epigraph from the start of this section. The American poet acknowledges everything in the places where they reside. And yet, he is also called to be "the arbiter of the diverse" and "the equalizer of his age and land." It is incumbent upon him to recognize the diversity of the demos, while at the same time regulating the differences, operating as this "equalizer." Whitman pursues this process of equalization through an incessant acknowledgment of both the political body and the lower classes throughout the text. His scrupulousness in recognizing and naming every part of the whole is an attempt at cultivating a democratic poetics, a poetics that holds the promise of pure equality.

\section{The Racial Subject and Sympathy's Limits}

Whitman's lengthy enumerations of the vast sects of American society, and his attempts to equalize them, also tell us something about a persistent attempt at sympathy. He makes his sympathetic ambitions explicit in "Song of Myself" when he proclaims, "I am he attesting sympathy:/Shall I make my list of things in the house and skip the house that/supports them?" (Whitman 37). This quote provides insights into a critical element of the text: Whitman isn't 
satisfied with simply recognizing and naming the components of the demos. Instead, he is interested in sympathetically engaging with them. One way this occurs is through an ethereal, bioelectrical type of sympathy. This sympathy is facilitated and supported by the overarching cosmic, metaphysical tone that permeates the entire work. Whitman's bioelectrical sympathy requires a cosmic, spiritual-like connection.

Walt Whitman, an American, one of the roughs, a kosmos, Disorderly fleshy and sensual ... eating drinking and breeding, No sentimentalist ... no stander above men and women or apart from them ... no more modest than immodest.

Unscrew the locks from the doors!

Unscrew the doors themselves from their jambs!

Whoever degrades another degrades me ... and whatever is done or Said returns at last to me,

And whatever I do or say also return. (Whitman 38)

Here, the framework for this bioelectrical sympathy is explicitly laid out. There is a symbiosis occuring between the poet and all of the people he is connecting with. His identification as "one of the roughs, a kosmos" situates himself as a medium of sorts, an ethereal being capable of receiving and transmitting energy from others. And yet, his cosmic qualities do not obliterate the physical self, the liberal subject. This is clear when he immediately follows the first line with "Disorderly fleshy and sensual ... eating drinking and breeding." The contradictions present here 
reflect the contradictions of the Spiritualist movement (a movement which Whitman was closely associated with at the time). This ideology held that identity is “...the expression of a spirit that is independent of the corporeal body (just like the classically Christian soul) and yet demonstrably material nonetheless" (Ellis 102). This excerpt demonstrates the presence of a bioelectrical Whitman, a porous self who can intimately relate with others at the end of this passage: "Whoever degrades another degrades me ... and whatever is done or/Said returns at last to me,/And whatever I do or say also return."

Another key way through which the poet expresses sympathy is through embodiment. An example of sympathetic embodiment comes in the following excerpt:

Agonies are one of my changes of my garments;

I do not ask the wounded person how he feels...I myself become the wounded person.

My hurt turns livid upon me as I lean on a cane and observe.

I am the mashed fireman with breastbone broken ... tumbling walls buried me in their debris,

Heat and smoke I inspired ... I heard the yelling shouts of my comrades,

I heard the distant click of their picks and shovels;

They have cleared the beams away ... they tenderly lift me forth. (Whitman 50) The poet doesn't even attempt to understand how the pained subject is feeling. Instead, he envelops him. This is a regular occurrence throughout the text, which conveys a notion of 
sympathy rooted in the corporeal. As Jane Bennett puts it, “...for (Whitman), the phenomenology of sympathy proceeds not by logic of projection so much as by dilation, or the opening wider of the pores of the body so as to receive more of the outside" (Bennett 610).

Indeed, sympathy is a driving thematic force at the heart of Whitman's pursuit of a democratic poetics. But it is critical to investigate sympathy's limits, and to identify where it deserves scrutiny in this work. In order to do this, I will look at how Whitman attempts to sympathize with a subjugated group: slaves.

In the Preface, the poet states, "To him enter the essences of the real things and past and present events...slavery and the tremulous spreading of hands to protect it, and the stern opposition to it which shall never cease till it ceases or the speaking of tongues and the moving of lips cease" (Whitman 5-6). This quote tells us something about Whitman's relationship to the institution of slavery in the text. There is an indifferent tone to this excerpt, as he describes both the opposition and support of slavery almost as a fact of life, as a cycle that will never end. Further, he doesn't take a position on the question of abolition. This absence of a pro or anti-slavery sentiment foregrounds a lack of care when describing the black, enslaved subject throughout the text. To investigate Whitman's depictions of the slave's subjugation, I submit that the poetics can be divided into two categories: celebration of the spectacle of slavery, and appropriation of black bodies through embodiment. Before explicating these categories in the text, I want to preface the discussion with a few remarks about the inextricable literary ties between blackness and slavery. When we talk about American slavery, we cannot understate the extent to which Africans inherited a long history on the meaning of blackness. American slaves 
were identified by a specific color, and that color held meaning long before they were enslaved. ${ }^{2}$ As a result, textually, as Toni Morrison comments, "Black slavery enriched [America's] creative possibilities. For in that construction of blackness and enslavement could be found not only the not-free but also, with the dramatic polarity created by skin color, the projection of the not-me" (Morrison 38). Understanding this interconnectedness of blackness and slavery will become important when dissecting the following excerpts from the text.

When describing the spectacle of slavery, I am referring to a staged, almost theatrical perception of the institution that non-slaveowning whites held. This "spectacle" was reflected in public presentations of slave life and the slave trade like the coffle, melodrama, minstrelsy, and sentimental abolitionist literature. Whitman depicts this spectacle regularly when writing about slavery, and it is noteworthy that he frequented minstrelsy shows in the pre-antebellum period. In fact, Whitman was denounced by contemporary reviewers as a "Bowery Boy" for the time he regularly spent in New York's Bowery District, a neighborhood infamous for its minstrelsy. ${ }^{3}$ To unpack Whitman's relationship to the spectacle of slavery, let's begin with the following excerpt:

The negro holds firmly the reins of his four horses ... the block swags underneath on its tied-over chain,

The negro that drives the huge dray of the stoneyard ... steady and tall he stands poised on one leg on the stringpiece,

His blue shirt exposes his ample neck and breast and loosens over his hipband,

His glance is calm and commanding ... he tosses the slouch of his hat

\footnotetext{
${ }^{2}$ Toni Morrison, Playing In The Dark

${ }^{3}$ Kenneth M. Price, To Walt Whitman, America
} 
away from his forehead,

The sun falls on his crispy hair and moustache ... falls on the black

of his polish'd and perfect limbs. (Whitman 28-29)

There is something romantic about the picture painted here. He is glorifying the slave in his labor, describing his work with an awe-struck and celebratory tone. The celebratory nature of this excerpt inadvertently renders the scene as one that is consensual. Furthermore, this pastoral scene undermines the intense structures of domination that held plantation life together. As Saidiya Hartman notes, "The pastoral renders the state of domination as an ideal of care, duty, familial obligation, gratitude, and humanity. The ruthless use of labor power and the extraction of slave profit are imagined as the consensual and rational exchange between owner and slave. This is accomplished by representing direct and primary forms of domination as coercive and consensual--in short, by representing slavery as a hegemonic social relation" (Hartman 53). Whitman's characterizations of the slave as "steady and tall" and "calm and commanding" lend themselves to a flawed depiction of an individual who is not only indifferent to his subjugation, but possibly even content with it. Indeed, this romantic characterization could not be more contrary to the real, violent conditions of chattel slavery. Further, this scene contains specific (and at times, erotic) depictions of the black body. The poet details "his ample neck and breast," "his crispy hair and moustache," and "his polish'd and perfect limbs." These specific corporeal images make a spectacle of the body, reinforcing its "suitability" to hard labor. The poet's fascination with specific body parts of the "picturesque giant" underscores an otherness, a difference between himself and the subject. And this fascination effectively insinuates that the slave is in his place undertaking forced manual labor. 
However, while Whitman acknowledges a difference between himself and the slave, he contradicts himself by the end of this excerpt when he "goes with the team also." Here, we see a movement away from observation, to active involvement in the hard labor. While the poet can observe, he can just as easily insert himself into the scene, imagining himself at work side-by-side with the enslaved. This poetic maneuver itself is an exercise in power. While the intention of Whitman's “common man" persona may be to align himself with any race or class of people, this voice becomes particularly problematic in this scene. This is because the speaker maintains a freedom and a privilege that allows him to perform this action. His ability to associate with the enslaved stems from a mythical pastoral scene that he has created. Certainly, Whitman's rendering of this picturesque, consensuel, benign scene undermines and even ignores the harsh material relations of chattel slavery. As a result, this flawed characterization is effectively a violent act.

Another place in which the institution of slavery was regularly spectacularized in pre-antebellum America was the coffle. Whitman generates a coffle scene in "I Sing The Body Electric":

A slave at auction!

I help the auctioneer ... the sloven does not half know his business.

Gentlemen look on this curious creature,

Whatever the bids of the bidders they cannot be high enough for him,

For him the globe lay preparing quintillions of years without one 
animal or plant,

For him the revolving cycles truly and steadily rolled.

In that head the allbaffling brain,

In it and below it the making of the attributes of heroes.

Examine these limbs, red black or white ... they are very cunning in tendon and nerve:

They shall be stript that you may see them.

Exquisite senses, lifelit eyes, pluck, volition.

Flakes of breastmuscle, pliant backbone and neck, flesh not flabby, goodsized arms and legs,

And wonders within there yet. (Whitman 96)

Here, Whitman moves past simple observation. Instead, he actively participates in the spectacle of the auction block. And the entire excerpt is dominated by this idea of the black subject's suitability for slave labor. He frames the slave as an ideal specimen, one which the bidders can't bid "high enough for him." The poet expounds upon this notion of suitedness when he lists specific images of the subject's body ("these limbs, red black or white," "exquisite senses," "flakes of breastmuscle," etc.). This corporeal imagery underscores the commodification of the black body. It explicitly conforms to the violent and brutal conditions of chattel slavery, the reduction of bodies to property. Further, the awe-struck and fascinated tone of admiration that 
pervades this excerpt conforms to the atmosphere that slave owners hoped to cultivate at the auction block for free, white onlookers. As Saidiya Hartman notes, the commodification of black bodies at the coffle prompted reflection about the human condition. The auction block, filled with slaves "striking it up lively" (performing songs and dances, putting smiles on their faces) was in itself a performance staged by slave owners for the purposes of undermining the violence of chattel slavery. As a result, “...violence becomes neutralized and the shocking readily assimilated to the normal, the everyday, the bearable. In effect, reflection acts to normalize the scene and deny the presence of violence by characterizing it as within the context of the socially endurable; and, accordingly, the scene shifts from one of despair to one of contentment and endurance" (Hartman 34-35). It is this sense of contentment and endurance that is cultivated through Whitman's corporeal imagery and overall tone of fascination and admiration.

In perpetuating the spectacle of slavery, Whitman doesn't simply glorify the slave in his everyday practices of forced labor. His depictions of the black subject aren't limited to the pastoral, to plantation life, or the coffle. He also details scenes of resistance and struggle. The characterizations of these scenes carry their own set of problems when it comes to the spectacularization of the institution. Let's look at an example from "Song of Myself":

The runaway slave came to my house and stopped outside,

I heard his motions crackling the twigs of the woodpile,

Through the swung half-door of the kitchen I saw him limpsey and weak,

And went where he sat on a log, and led him in and assured him, And brought water and filled a tub for his sweated body and bruised 
feet,

And gave him a room that entered from my own, and gave him some coarse clean clothes,

And remember perfectly well his revolving eyes and his awkwardness,

And remember putting plasters on the galls of his neck and ankles;

He staid with me a week before he was recuperated and passed north,

I had him sit next to me at table ... my firelock leaned in the corner. (Whitman 27-28)

It's valuable to start by looking at how the imagery is functioning here. The most powerful images in this excerpt are corporeal ("limpsey and/weak," "sweated body and bruised/feet," "the galls of his neck and ankles"). Whitman's bodily depictions are clearly used to convey the pain of the enslaved body. However, the extent to which this runaway slave is described revolves around bodily consequences of violence. He exists only as a vessel for sympathy, as one who should be pitied because of the physical trespasses committed against him. With this in mind, this passage is a clear example of violence engendering blackness. Another element of this excerpt worth exploration is how the speaker situates himself. The content and tone make clear that the speaker frames himself as a guardian, as a just white ally willing to risk his livelihood to support a runaway slave. This character is one who gave the runaway a room, clean clothes, and a bath. Certainly, the speaker performs actions that are morally commendable. However, there is something problematic about Whitman framing himself as this speaker. The most obvious reason is the fact that Whitman never sheltered slaves, he never actually assisted them in escaping to their freedom. Another reason is this passage doesn't do proper justice to the imminent fear and danger that actually surrounded a scene like this in real life. Whitman's presentation of this scene 
undermines the immense risk taken by those who participated in the underground railroad. Instead, the tone of this passage frames this encounter in a sentimental light, similar to the contemporary abolitionist theater and literature of its time.

Whitman's presentation of the black slave isn't limited to the spectacularization of the slave trade. Instead, it moves into full-fledged embodiment. Whitman's use of sympathy through embodiment has already been briefly explored. Indeed, his attempts to become others is an intriguing poetic maneuver, one that conveys an intimate notion of sympathy located at specific sites within the body. However, these attempts at sympathy become problematic, particularly when it comes to Whitman's portrayal of the black subject. Early in the text, he proclaims, "Through me many long dumb voices,/Voices of the interminable generations of slaves..." will be heard (Whitman 39). This proclamation sets a precedent for how the poet engages with the body of the slave throughout the text.

Let's begin by looking at a passage where Whitman does this from "I Sing The Body Electric":

The hounded slave that flags in the race and leans by the fence, blowing and covered with sweat,

The twinges that sting like needles his legs and neck, The murderous buckshot and the bullets, All these I feel or am.

I am the hounded slave ... I wince at the bite of dogs, Hell and despair are upon me ... crack and again crack the 
marksmen,

I clutch the rails of the fence ... my gore dribs thinned with the ooze of my skin,

I fall on the weeds and stones,

The riders spur their unwilling horses and haul close,

They taunt my dizzy ears ... they beat me violently over the head with their whip-stocks. (Whitman 50)

It is useful to start by looking at the structure of this excerpt. The poet acknowledges the "hounded slave," describing the physical terrors he encounters. But he ends this stanza by steadily shifting towards physical embodiment ("All these I feel or am") before he comes to consume the black subject in the following stanza. At this point, he isn't only observing and recording this dangerous scene (which we've already explored as a potential act of violence). Rather, he takes on the site of suffering ("I am the hounded slave"). Whitman's embodiment of the slave deserves scrutiny here, as this maneuver is clearly performed for the purposes of invoking the sympathy of the reader.

The descriptive language that follows his embodiment revolves strictly around the violent nature of the scene. These intense images operate to convey the pain and suffering of the speaker. Thus, we see a clear instance where blackness and suffering are inextricably intertwined in the text. One doesn't exist outside of the other. This begs the question: why does Whitman have to become the other in order to sympathize with his suffering? The answer has something to do with the construction of blackness. Further, it has something to do with notions of black sentience and the black subject's threshold for pain, his so-called "suitability" to the institution 
of slavery. As we have already seen, Leaves of Grass engages with the spectacle of slavery in a way that conforms to these problematic notions of suitedness. However, in the aforementioned coffle scene, this is conducted through a pro-slavery approach ("I help the auctioneer"). In the sentimental, abolitionist approach of this excerpt, the poet embodies the slave in an attempt to establish that the black subject possesses the same nature and feelings as himself. This is an effort to "...establish the common humanity of all men on the basis of this extended suffering..." (Hartman 18). While the poet's intention in pursuing this kind of embodied sympathy may be just, it is only made possible by what Saidiya Hartman would call the fungibility of the captive body. It inevitably reinforces a racist trope of limited sentience and high pain tolerance as qualities inherent to blackness. In turn, “...the humanity of the slave inadvertently confirms the expectations and desires definitive of the relations of chattel slavery." Indeed, this scene offers a problematic combination: the spectacularization of slavery and a sentimental embodiment of the enslaved subject. This combination inevitably undercuts the poet's abolitionist intentions here.

Another example of such embodiment comes in the infamous Lucifer depiction in "The Sleepers":

Now Lucifer was not dead ... or if he was I am his sorrowful terrible heir;

I have been wronged ... I am oppressed ... I hate him that oppresses me,

I will either destroy him, or he shall release me.

Damn him! How he does defile me, 
How he informs against my brother and sister and takes pay for their blood,

How he laughs when I look down the bend after the steamboat that carries away my woman.

Now the vast dusk bulk that is the whale's bulk ... it seems mine,

Warily, sportsman! though I lie so sleepy and sluggish, my tap is death. (Whitman 88-89) Before examining the poetic content of this excerpt, it's worthwhile to provide some historical context for the language used here. The name Lucifer most obviously alludes to the rebellious angel. It is also noteworthy that one definition of Lucifer in mid-nineteenth-century dictionaries was an easily-ignitable match. These matches were also called loco-focos. Further, "locofocos" was the name given to the radical wing of the Democratic Party during the pre-antebellum period. The locofocos held a strong anti-slavery position. ${ }^{4}$ Thus, as Ed Folsom details, “Underlying Whitman's choice of a name for his first slave character, then, was his own early admiration of the Locofocos...Whitman's Lucifer was a 'combustible substance,' too, a lucifer-match flaming into an expression of hate and rage and threatening to turn his apparent sluggishness into a massive movement of death, a loco-foco slave ignited by a lifetime of friction with his cruel master and with the dehumanizing institution of slavery” (Folsom 49).

Indeed, when considering its historical context, this passage may be the most explicit instance of anti-slavery rhetoric in the text. However, this passage contains its own set of issues when it comes to the racial subject. First, while these stanzas aren't as rich in violent imagery as

\footnotetext{
${ }^{4}$ Ed Folsom, "Lucifer and Ethiopia: Whitman, Race, and Poetics before the Civil War and After"
} 
some of the aforementioned examples, they are certainly just as sentimental. This is evident when the poet details the series of wrongs committed against him by the slavemaster. Further, Whitman's embodiment of the black subject is just as problematic here. In order to relate to the slave, in order to understand that he and the slave share common feelings, the poet has to place himself inside of the fungible, black body. In this instance, he doesn't necessarily appropriate the sufferings of the slave so much as he appropriates the anger of the slave ("I am oppressed," "How he does defile me," etc.). His assumption of the role of the outraged black subject conveys an attempt to use rage as the common language of humanity. He is only able to situate black sentience on equal footing with white sentience through this dialect of rage.

With all of these textual examples in mind, it's abundantly clear that Whitman's relationship to the racial subject can be divided into two categories: celebration of the spectacle of slavery, and appropriation of black bodies through embodiment. Through these lenses, it is evident that the poet's portrayal of the racial subject is misguided at best, and vehemently racist at worst. The aforementioned textual examples constitute what Toni Morrison would call the "Africanist persona" in American literature. For Whitman, the black subject offers “...an extraordinary meditation on the self; a powerful exploration of the fears and desires that reside in the writerly conscious. It is an astonishing revelation of longing, of terror, of perplexity, of shame and magnanimity" (Morrison 17). But what does this mean? It's necessary for us to ask what is at stake here? What effect does this have on the text as a whole? The answer is twofold. First, the spectacle that Whitman creates when characterizing the slave (a spectacle which occurs in some form in each of the passages we have explored) operates to efface the violence inflicted upon him. It undermines the pain and suffering innate to the institution by perpetuating myths of 
limited black sentience and tolerance for pain. It is this effacing of violence that enables us to understand the second component to this answer, one that deals with the question of embodiment. The poet is able to become the black body precisely because he has undermined the violence of slavery. His undermining of slavery's violence allows him to take advantage of the fungibility of the slave's body. It “...makes the captive body an abstract and empty vessel vulnerable to the projection of others' feelings, ideas, desires, and values...” (Hartman 21). Indeed, the poet's embodiment of the slave can be read as an effort made with just intentions. $\mathrm{He}$ is, after all, attempting to find a common humanity between himself and the subjugated, to feel and relate to his suffering. It's an effort to bridge the gap between himself and the other. However, it is this form of embodiment that effectively erases the other. It constricts the space for dialogue, affording him no room to speak for himself in the conversation. As a result, throughout the text, it is in "making the other's suffering one's own, (that) suffering is occluded by the other's obliteration" (Hartman 19). This "obliteration" reinforces the slave's submission not only to his master, but to all whites.

\section{Hegemony and the Undermining of the Demos}

Whitman's relationship to the racial subject in the text raises a series of problems when it comes to his project of a democratic poetics. By now it is clear that his spectacularization of slavery and his embodiment of the enslaved are themselves violent acts. But what effect does this have on his poetic exploration of the demos?

In order to answer this question, we need to return to defining the demos. Giorgio Agamben characterizes an inherent dichotomy in the "demos." He describes how the French, English, Latin, Spanish, and Italian words for demos, “...designate both the complex of citizens 
as a unitary political body (as in "the Italian people" or "the people's judge") and the members of the lower classes (as in homme du people, rione popolare, front populaire). Even the English word 'people,' which has a less differentiated meaning, still conserves the sense of 'ordinary people' in contrast to the rich and the nobility" (Agamben 176-177). Agamben's definition of a binary demos, one that includes both the political body and the poor, functions well when we situate it within the poet's effort to recognize and name each component of American society, every part of the whole. But when it comes to slaves, a massive sect of society that wasn't even considered a people, Agamben's definition falls short. Slaves are neither the political body nor are they the poor. In essence, they are, as Jacques Ranciere would put it, the part that has no part. The enslaved are, in this case, the miscounted. According to Ranciere's logic, democracy only occurs when the miscounted disrupt "...the order of the distribution of bodies as a community" (Ranciere 99). However, in order for this disruption to occur, the miscounted must organize and speak for themselves. And as we've seen in the text, the poet hardly, if ever, allows the black, enslaved subject to speak for himself. While Whitman may have had good intentions in speaking for the slave, his efforts demonstrate how “...empathy fails to expand the space of the other, merely plac(ing) the self in its stead" (Hartman 20). His portrayal of the enslaved demonstrates "...the dangers of a too-easy intimacy, the consideration of the self that occurs at the expense of the slave's suffering, and the violence of identification" (Hartman 20). On the one hand, Whitman's spectacularization of the institution is demonstrative of this violence of identification. It downplays the suffering of the slave, denying his sentience and keeping him "in his place" as the miscounted. On the other, his empathetic efforts in speaking for and becoming the enslaved body constricts the space in which the miscounted can disrupt the social order. In embodying the 
slave, Whitman prevents him from speaking for himself, denying him the opportunity for disruption. By not allowing the slave to speak on his own, he effectively shuts down a space for democracy to occur.

With this in mind, it's clear that Whitman's relationship to the black, enslaved subject inadvertently undermines the pursuit of a democratic poetics. The revelation that this work is, in many ways, antidemocratic can have serious consequences on how it is understood within the American literary tradition. Leaves of Grass has been studied and revered in the American public education system for well over a century, and Whitmanian poetics continue to figure prominently in American consciousness. The finale of the 62nd Annual Grammy Awards in 2020 consisted of a performance of "I Sing the Body Electric," complete with performances from a star-studded cast of musicians, singers, and dancers. Further, a recent article in The New Yorker commenting on the benefits of slavery reenactments asserts:

"Identifying with fugitives is nothing new in America. 'I am the hounded slave, I wince at the bite of dogs,' Walt Whitman wrote, in 'Song of Myself.' D.H. Lawrence once described the country as 'a vast republic of escaped slaves.' More recently, the runaway has emerged as the emblematic figure of a renovated national mythology, hero of a land that increasingly sees its Founding Fathers as settler-colonist genocidaires. In their stead rises a patriotism centered on slavery and abolition, and a campaign to set the country's age-old freedom cult on a newly progressive footing" (Lucas 41)

The reference to this problematic excerpt from "I Sing The Body Electric" without any scrutiny is noteworthy. And it can tell us something about the role Whitmanian sympathy has played in an American understanding of history. The presentation of Leaves of Grass as a great work of 
equality, a piece that celebrates a progressive multicultural vision of American identity, can be interpreted as a hegemonic structure.

For the purposes of this argument, it's important to understand hegemony as the establishment of a specific form of domination that has, according to quote Stuart Hall, “...the capacity to actively contain, educate, and reshape oppositional forces, to maintain them in their subordinate places" (Hall 169). Further, it is the formation of a historical bloc "...that combines the leading section of the dominant class with subaltern and subordinate sections of other classes" to establish political rule (Hall 169). When it comes to the poet's relationship to race and slavery in the text, two key themes emerge: free labor and sentimentalism. We see the ideology of free labor played out in the passages that detail the difficult work of the slave, celebrating his persistence and determination in decrying the lack of dignity afforded him. And sentimentalism is clearly at work in Whitman's intimate, detailed attempts to empathize with the slave, in his embodiment of the slave.

Free labor and sentimentalism can both be understood as forms of hegemony. Most abolitionists in the mid-19th century adhered to the ideology of free labor, as it, in the words of Eric Foner, “...provided an appeal on which all Republicans could unite. It was an appeal to the lowest common denominator of party ideology, allowing Republicans to sidestep both the problem of race and the effects of slavery upon the enslaved" (Foner 59). The free labor movement offers us a clear example of the formation of a historical bloc in which the State adapted, making concessions on the slavery question while still maintaining control through the means of coercion and consent. The strength of this movement in the pre-antebellum period is demonstrative of the State's anticipation of a societal change (the abolition of slavery), and its 
ability to adapt to maintain control in the aftermath of that change. Sentimentalism, specifically abolitionist sentimentalism, operated similarly. The ideological centerpiece of abolitionist sentimentalism is the notion that putting one's self in the shoes of the subjugated will inevitably lead him to understand the pain and suffering of that individual. But abolitionist sentimentalism fundamentally discounted the limits and dangers of sympathy. Further, as we have already discussed, it reinscribed violence on the black body, denying the sentience of the enslaved. The hegemony of the free labor movement allowed solidarity across racial lines to dissolve once slavery had been abolished, opening the door to the failures of Reconstruction. The hegemony of abolitionist sentimentalism still operates today in the ways that a work like Leaves of Grass is celebrated as a poetics of democracy. In popular culture, the lack of scrutiny that persists when it comes to Whitman's empathization with subjugated groups continues to perpetuate dangerous notions of how multiculturalism is achieved. The spectacularization and embodiment of the other doesn't give him a voice in the American democratic discussion. Instead, it fundamentally excludes him from the conversation, affording him no space to speak for himself. 


\section{Works Cited}

Agamben, Giorgio. Homo Sacer. Stanford, 1998.

Bennett, Jane. “Whitman's Sympathies.” Political Research Quarterly, vol. 69, no. 3, Sept. 2016, pp. 607-620, doi:10.1177/1065912916656824. Accessed 15 January 2020.

Brown, Wendy. Undoing The Demos: Neoliberalism's Stealth Revolution. Zone Books, 2015.

Ellis, Cristin. Antebellum Posthuman: Race and Materiality in the Mid-Nineteenth Century. Fordham University Press, 2018. Project MUSE, doi:10.1353/book.57236. Accessed 15 January 2020.

Folsom, Ed. "Lucifer and Ethiopia: Whitman, Race, and Poetics before the Civil War and After." A Historical Guide to Walt Whitman, edited by David S. Reynolds, Oxford, 2000, pp. 45-95.

Foner, Eric. Free Soil, Free Labor, Free Men: The Ideology of the Republican Party Before The Civil War. Oxford, 1995.

Hall, Stuart. "Lecture 7: Domination and Hegemony." Cultural Studies 1983, edited by Jennifer Daryl Slack and Lawrence Grossberg, Duke, 2016, pp. 155-179.

Hartman, Sadiya. Scenes of Subjection: Terror, Slavery, and Self-Making in Nineteenth-Century America. Oxford, 1997.

Lucas, Julian. "The Fugitive Cure: Can slavery reenactments set us free?" The New Yorker, 17 \& 24 February 2020, pp. 40-47.

Morrison, Toni. Playing in the Dark: Whiteness and the Literary Imagination. Vintage Books, 1993. 
Price, Kenneth M. To Walt Whitman, America. Kenneth M. Price, 2004.

Ranciere, Jacques. Disagreement. University of Minnesota, 1999.

Whitman, Walt. Leaves of Grass: The Original 1855 Edition. Dover, 2007.

Whitman, Walt. "Walt Whitman and His Poems." September 1855. The Walt Whitman Archive, edited by Ed Folsom and Kenneth M. Price. www.whitmanarchive.org. Accessed 14 May 2020. 